\title{
Peran Bidan dalam Parenting Education Sebagai Upaya Peningkatan Tumbuh Kembang Anak Usia Dini
}

\author{
Tri Sunarsih ${ }^{1 *}$

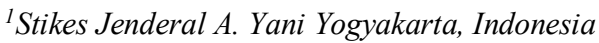

\author{
Informasi Artikel: \\ Diterima: September, 2015 \\ Disetujui: Oktober, 2015 \\ * Korespondensi penulis. \\ are_she79@yahoo.com
}

\begin{abstract}
ABSTRAK
Pelaksanaan promosi kesehatan melalui parenting education di PAUD holistik integratif adalah wadah pendidikan orangtua untuk meningkatan pola asuh kepada anak, agar anak dapat tumbuh dan berkembang secara optimal. Bidan memiliki tugas dalam promosi kesehatan. Tujuan penelitian ini adalah untuk menganalisis pengaruh faktor peran bidan desa dalam proses promosi kesehatan melalui parenting education di PAUD holistik integratif yang berpengaruh secara langsung maupun tidak langsung terhadap pola asuh orangtua secara holistik di Kabupaten Karanganyar.
\end{abstract}

Penelitian ini dilakukan di wilayah Kabupaten Karanganyar, Jawa Tengah. Penelitian ini adalah penelitian survei dengan disain cross-sectional yang menggunakan kuesioner sebagai instrumen utama pengumpulan data primer. Data sekunder diperoleh dari pencatatan di instansi terkait di Kabupaten Karanganyar. Sampel yang diperoleh adalah sebanyak 108 orangtua, yang diambil dengan teknik purposive sampling. Analisis penelitian adalah regresi linier berganda dan model analisis jalur (path analysis).

Temuan-temuan pentingnya adalah bahwa secara bersama-sama (simultan) peran bidan desa, peran pendidik PAUD, peran petugas PLKB, dan proses promosi kesehatan melalui parenting education berpengaruh signifikan baik langsung maupun tidak langsung terhadap pola asuh orangtua secara holistik. Secara parsial, peran bidan desa, peran pendidik PAUD, peran petugas PLKB serta proses promosi kesehatan melalui parenting education berpengaruh signifikan terhadap pola asuh orangtua secara holistik. Strategi promosi kesehatan melalui parenting education yang tepat adalah dengan peningkatan kerjasama lintas sektor.

Kata kunci: peran bidan; parenting education; anak usia dini

\begin{abstract}
Implementation of health promotion through parenting education in holistic integrative earcly childhood education (PAUD) is a medium for parental education to improve parenting to children, so that children can grow and develop optimally. Holistic integrative education in early childhood among Posyandu, Education for Family with Toddler, and Early Childhood Education is a new paradigm; thus, there is a need for a strategy that combines three aspects: nutrition, health, psychosocial, and education. This research aimed to analyze the influence of the role of village midwife in health promotion process through parenting education in holistic integrative PAUD that impacts directly or indirectly on parenting parents holistically in Karanganyar District.
\end{abstract}

This research was conducted in the Region of Karanganyar District, Central Java. This was a survey research with a cross-sectional design, using questionnaires as the main instrument to collect primary data. Secondary data were obtained from records in the relevant agencies in Karanganyar District. The sample size was 108 parents, taken by using purposive sampling technique. This research used multiple linear regression analysis and path analysis model.

The findings were that, simultaneously and partially, the roles of village midwife, PAUD educator, and family planning outreach worker as well as the process of health promotion through parenting education had significant effects both directly and indirectly on holistic parenting. Strategy for health promotion through appropriate parenting education can be done with the improvement of multi sectoral cooperation.

Key words, Midwives's roles; Parenting education, early childhood 


\section{PENDAHULUAN}

Pilar utama kemajuan suatu bangsa sangatlah ditentukan oleh kualitas Sumber Daya Manuasia (SDM) yang dimiliki, yaitu SDM yang memiliki fisik yang tangguh, mental yang kuat dan kesehatan yang prima di samping tingkat intelegensia, kematangan emosional, dan spiritual yang tinggi. Makin berkembangnya era globalisasi yang mengikis kaidah-kaidah moral budaya bangsa melengkapi kerumitan masalah mutu SDM di Indonesia. Kemudahan akses informasi membawa terjadinya penetrasi global dari model-model gaya hidup yang sering tidak cocok dengan realita lokal (Mursitho, 2014). Secara empirik, hampir setiap hari kita disuguhkan pemandangan peristiwa yang mengerikan, seperti pembunuhan, perampokan, pemerkosaan, konflik antar kelompok, perkelahian antar suku, tawuran pelajar/mahasiswa, penyalahgunaan obat terlarang narkotika, peredaran foto dan video porno, dan lain-lain. Salah satu kasus yang beredar luas sekarang ini adalah kasus sodomi maupun pelecehan seksual yang dilakukan oleh tenaga pendidik (Siregar, 2014).

Krisis ekonomi yang berkepanjangan dan gelombang "reformasi total" membuat banyak ibuibu untuk ikut bekerja di luar rumah. Anak menjadi kesepian karena sering ditinggal sendiri, dan asuhan diserahkan kepada orang lain, sehingga anak terlalu banyak menonton TV, video, dan game online (Sindhunata, 2003). "Defisit pendidikan informal" (pendidikan di lingkungan keluarga) akhirnya tidak terelakkan untuk terjadi. Jadi, pendidikan informal (keluarga) ternyata kurang dapat memberikan sahamnya baik dalam hal pembangunan watak, kepribadian, dan karakter, serta tidak dapat membekali nilai-nilai hidup (Mursitho, 2014).

Upaya membangun SDM yang berkualitas tentu harus lebih difokuskan pada kelompok sasaran yang paling strategis, yaitu kelompok usia dini, karena periode ini merupakan periode kritis (critical period) bagi perkembangan otak balita. Para ahli menyebut periode ini sebagai "masa emas" (golden ages), "jendela kesempatan" (window of opportunity) (Depkes RI, 2005). Sejak dini, anak-anak perlu ditanamkan nilai-nilai moral sebagai pengatur sikap dan perilaku individu dalam melakukan interaksi sosial di lingkungan keluarga, masyarakat, maupun bangsa.

Sering kali orangtua menghambat proses pembelajaran yang dilakukan oleh pendidik, dari akibat ketidaktahuan orangtua tentang cara mendidik anak yang baik. Ketidakmampuan untuk menghadapi perubahan-perubahan tersebut menghasilkan keluarga-keluarga yang tidak mampu berfungsi sebagaimana mestinya (dysfunctional families). Program yang sedang digalakkan adalah pendidikan keorangtuaan (parenting education) untuk memperkuat peran orang tua dan keluarga dalam pendidikan di jalur informal. Program ini sangat populis dan berdampak langsung dalam dinamika sosial, ekonomi, politik, dan budaya serta peradaban, tetapi selama ini justru pemerintah mengabaikannya, dengan terlihatnya dukungan anggaran yang terbatas. Kartu Indonesia Pintar (KIP) dan Kartu Indonesia Sehat (KIS) juga belum dapat menjangkau pendidikan nonformal dan informal (Nomi, 2014).

Lingkungan asuhan terutama interaksi ibu-anak, pola asuh, dan stimulasi keluarga mempengaruhi pertumbuhan dan perkembangan anak, selain karakteristik keluarga, ibu dan anak, serta konsumsi makanan (Satoto, 1990; Madanijah, 2005). Sejalan dengan pendapat Mulyasa (2012), keluarga adalah lembaga pendidikan pertama dan utama dalam membentuk jati diri anak. Watak-watak anak untuk pertama kalinya berkembang dalam institusi keluarga (Bronfenbrenner, 1979). Pendidikan dalam keluarga yang tepat dan benar merupakan modal dasar bagi perkembangan kepribadian anak pada masa dewasanya. Dalam konteks inilah, pengasuhan anak menjadi sangat penting, karena melalui proses pengasuhan, anak tumbuh dan berkembang menjadi sosok individu dengan seperangkat karakteristik yang sejalan dengan apa yang diterima selama proses pengasuhan berlangsung.

Dari sisi kelembagaan penyelenggara pelayanan, berbagai lembaga pelayanan sudah melakukan pelayanan untuk pendidikan orangtua, seperti BKKBN dengan kelompok Bina Keluarga Balita 
(BKB), Kementrian Pendidikan Nasional dengan Pendidikan Anak Usia Dini Berbasis Keluarga, Kementrian Kesehatan dengan Kelompok Ibu Balita, dan sebagainya. Baik BKB, PAUD berbasis keluarga, maupun Kelompok Ibu Balita merupakan program yang bertujuan untuk meningkatkan pengetahuan, sikap, keterampilan orangtua dan anggota keluarga lainnya dalam mengasuh dan membina tumbuh kembang balita melalui rangsangan fisik, kecerdasan, emosional maupun sosial spiritual melalui interaksi efektif antara orangtua dan anaknya.

Hasil kajian tentang parenting education menunjukkan bahwa keterampilan orangtua dalam menjalankan fungsi pengasuhan adalah masih rendah (Syakrani, 2004). Terdapat beberapa faktor penyebab tentang hal ini, antara lain, kurang siapnya calon orangtua untuk membina keluarga dan menjadi orangtua, tidak ada program parenting, rendahnya pemahaman dan kesadaran orangtua tentang arti penting dan pengaruh keayahbundaan terhadap tumbuh kembang anak, rendahnya komitmen komunitas khususnya pemerintah terhadap pemberdayaan (institusi) keluarga, dan kurangnya informasi tentang pentingnya pengasuhan terhadap anak. Hal tersebut sejalan dengan penelitian yang dilakukan oleh Shochib (2010) bahwa pengetahuan dan sikap orangtua dalam memberikan pola asuh terhadap anaknya dipengaruhi oleh kurangnya informasi tentang cara-cara mencapai hidup sehat yang dapat menyebabkan penyimpangan pola asuh terhadap anak. Oleh karena itu, kajian tentang pelaksanaan parenting education di PAUD Holistik Integratif sangat diperlukan, untuk mengetahui dampaknya terhadap pola asuh anak, agar anak dapat tumbuh dan berkembang secara optimal serta untuk mewujudkan Anak Indonesia Harapan (AIH) yang merupakan hadiah 100 tahun Indonesia merdeka (2045) (Kemdiknas, 2011).

Di pihak lain, penelitian tentang promosi kesehatan saat ini lebih banyak melakukan intervensi pada metode promosi kesehatan dan dihubungkan dengan perubahan pengetahuan, sikap, dan perilaku individu serta masih jarang penelitian yang mengaitkan dengan peran bidan. Penelitian program parenting tentang stres pengasuhan dan self-efficacy dilakukan oleh Kitaoka dkk (2013) dengan hasil bahwa terdapat manfaat bagi orangtua dalam hal meningkatkan kepercayaan diri dan mengurangi stres. Penelitian tentang perbedaan persepsi orangtua dan guru tentang strategi keterlibatan orangtua dalam pengasuhan berdasarkan faktor demografi dilakukan oleh Morgan (2009) yang menunjukkan bahwa orangtua dan guru memiliki perbedaan yang signifikan dalam pandangan mereka dalam mendefinisikan keterlibatan orangtua, dan perbedaan tersebut terlihat jelas ketika beberapa faktor demografi dipertimbangkan. Penelitian tentang peran perilaku orangtua dalam transmisi antar generasi dalam kehidupan sosial dilakukan oleh Hsin (2008) yang menunjukkan bahwa waktu orangtua tidak cukup untuk menghasilkan prestasi yang positif dan penelitian tentang partisipasi dilakukan oleh Larne (2009) menunjukkan bahwa identitas diri dan norma kelompok secara signifikan berpengaruh pada niat untuk berpartisipasi dalam pendidikan orangtua.

Walaupun sudah ada PAUD holistik integratif (LIPI, 1998; Madanijah, 2005), program parenting yang merupakan bagian program PAUD belum dilaksanakan secara integrasi, terutama tentang pelaksanaan dan materi yang diberikan. Koordinasi dalam rangka mengisi atau melengkapi kegiatannya hampir tidak pernah terjadi, sementara untuk materi yang diberikan mestinya harus terdapat sinkronisasi. Penelitian Handayani (2011) menambahkan bahwa pemahaman akan pentingnya pengembangan anak usia dini yang holistik-integratif dari para pemangku kepentingan (stakeholder), baik dari para pengambil kebijakan, penyelenggara dan masyarakat termasuk di dalamnya bidan desa, kader kesehatan adalah masih terbatas.

Dimasukkannya faktor komunitas adalah sejalan dengan preskripsi tesis children of the universe dan perhatian banyak kalangan terhadap pola asuh orangtua (Syakrani, 2004). Karena itu, kajian tentang parenting education dalam kaitannya dengan pola asuh orangtua secara holistik bukan saja mempertimbangkan faktor yang terdapat pada level individu dan keluarga, tetapi juga faktor komunitas. Dukungan komunitas sangat dibutuhkan, 
terutama untuk menguatkan keterampilan pola asuh orangtua. Dukungan komunitas dalam penelitian ini adalah sebagai fasilitator atau agen perubahan (change agent). Faktor ini mencakup peran bidan desa, petugas PLKB, pendidik PAUD, dan kader. Semua faktor yang secara teoretik diduga berpengaruh positif terhadap parenting education dan pola asuh orangtua secara holistik digubah dan diseleksi untuk menjadi kerangka pemikiran penelitian.

Bidan desa, petugas PLKB, pendidik PAUD, dan kader pemberdayaan masyarakat memiliki peran penting dalam memunculkan dan meningkatkan kesadaran masyarakat. Peran (role) merupakan pola perilaku dan sikap yang diharapkan dari seseorang karena status ataupun kedudukannya (Robbins, 2002). Bidan desa, petugas PLKB, pendidik PAUD, dan kader memiliki peran pula sebagai motivator dan community organizers (Midgley, 1986).

Bidan desa, petugas PLKB, pendidik PAUD, dan kader sebagai fasilitator pada hakekatnya memiliki peran ganda, yaitu sebagai guru, penganalisis, penasehat, dan organisator (Mardikanto, 2010). Lebih lanjut, fasilitator pemberdayaan masyarakat secara singkat dapat disebut sebagai peran 'edfikasi', yaitu akronim dari peran edukasi, diseminasi inovasi, fasilitasi, konsultasi, advokasi, supervisi, pemantau (monitoring) dan evaluasi. Peran-peran stakeholder yang ada tersebut menurut Butterfield dkk (2004) dibagi dalam 6 kelompok, yaitu pemotivasi, pembentuk, moderator pembentuk, operasional, hasil atau outcomes, dan moderator hasil atau moderator outcomes. Peran stakeholder baik bidan desa, petugas PLKB, pendidik PAUD, dan kader kesehatan yang dikaji dalam penelitian ini adalah peran sebagai fasilitator, dinamisator, inovator, motivator, pembina, pengumpul, dan penyebar informasi.

\section{BAHAN DAN METODE}

Berdasarkan tujuan penelitian, jenis penelitian yang digunakan adalah penelitian kuantitatif jenis explanatory study. Untuk mendukung dan mempertajam analisis, penelitian ini dilengkapi dengan informasi berdasarkan data kualitatif
(Brannen, 2002). Pelaksanaan penelitian ini menggunakan metode survei dengan pendekatan cross sectional. Penelitian ini dilakukan pada PAUD Holistik Integratif yang menyinergikan Pos PAUD, BKB, dan Posyandu, yaitu di lima lokasi terpilih: 1) PAUD Nakita Wetan Kali, Girilayu, Matesih; 2) PAUD Kasih Bunda Panjang, Sepanjang, Tawangmangu; 3) PAUD Mawar Putih Krangean, Ngeblak, Tawangmangu; 4) PAUD Amanah Dagen, Dagen, Jaten; dan 5) PAUD Seruni Sehat Jl. Jeruk 03 Ngringo, Jaten.

Populasi dalam penelitian ini adalah orangtua dari anak usia dini yang mengikuti PAUD Holistik Integratif satu atap yang berjumlah 108 orang. Teknik sampling yang digunakan adalah teknik purposive sampling. Teknik pengumpulan data dengan kuesioner, wawancara mendalam (in-depth interview), studi dokumentasi, dan observasi. Dalam penelitian ini, analisa data menggunakan analisis regresi linier berganda dan analisis jalur (path analysis). Data diubah dengan menggunakan Metode Suksesive Interval (MSI) terlebih dahulu dan kemudian pengujian dilakukan terhadap asumsi parametrik, yaitu normalitas, linieritas, multikolinieritas, dan heteroskedastisitas, sehingga menghasilkan BLUE (Best Linear Unbiased Estimator) (Sandjojo, 2011).

\section{HASIL DAN PEMBAHASAN}

Bidan sebagai ujung tombak pelayanan kesehatan di desa mempunyai tugas pokok dan fungsi meningkatkan peran serta masyarakat dalam pembinaan kesehatan ibu dan anak di wilayah kerjanya (Depkes, 1997). Peran bidan desa dalam penelitian ini dilihat dari perannya sebagai motivator, dinamisator, fasilitator, maupun pembina dalam program parenting education yang difokuskan pada persoalan sejauh mana peran masing-masing secara faktual memiliki nilai fasilitatif bagi orangtua dalam menjalankan tugas pola asuhnya, yaitu penilaian subyektif kepuasan orangtua. Di samping peran bidan desa, karena lokasi penelitian adalah di PAUD Holistik Integratif untuk melihat sinergisitas tugas dan tanggungjawab stakeholder, peran kader kesehatan, peran PLKB dan peran pendidik PAUD juga diteliti. 
Berdasarkan hasil analisis peran bidan desa, peran kader kesehatan, peran PLKB, dan peran pendidik PAUD dengan pola asuh orangtua secara holistik, nilai $\left(\mathrm{r}_{\mathrm{XY}}\right)$ yang didapat adalah sebesar 0,53 dan koefisien korelasi parsial ( $\mathrm{r}_{\text {Parsial }}$ ) adalah sebesar 0,20 dengan $\mathrm{p}<0,05$. Hasil ini diperkuat dengan hasil analisis dengan koefisien beta $(\beta)$ dari variabel peran stakeholders yang sebesar 0,11 dan $t_{\text {hitung }} 2,075$ dengan $\mathrm{p}<0,05$. Nilai $\mathrm{p}<0,05$ dapat disimpulkan bahwa terdapat pengaruh positif yang signifikan dari faktor peran stakeholders terhadap pola asuh orangtua secara holistik di PAUD Holistik Integratif Kabupaten Karanganyar. Pengaruh langsung dan tidak langsung masing-masing variabel eksogen (independent variable) terhadap variabel endogen (dependent variable) adalah sebagai berikut:

\section{Tabel 1}

Pengaruh Langsung (Direct) dan Tak Langsung (Indirect) Peran terhadap Pola Asuh Anak Secara Holistik

\begin{tabular}{|c|c|c|c|c|}
\hline \multirow{2}{*}{$\begin{array}{c}\text { Variabel } \\
\text { Endogen/ } \\
\text { Dependent }\end{array}$} & \multirow{2}{*}{$\begin{array}{c}\text { Variabel } \\
\text { Eksogen/ } \\
\text { Independent }\end{array}$} & \multicolumn{3}{|c|}{ Pengaruh (\%) } \\
\hline & & Langsung & $\begin{array}{c}\text { Tidak } \\
\text { Langsung }\end{array}$ & Total \\
\hline $\begin{array}{l}\text { Proses } \\
\text { Promosi }\end{array}$ & $\begin{array}{c}\text { Peran Bidan } \\
\text { Desa }\end{array}$ & 12,3 & -- & 12,3 \\
\hline $\begin{array}{l}\text { Kesehatan } \\
\text { Melalui }\end{array}$ & Peran Kader & $-1,0$ & -- & $-1,0$ \\
\hline \multirow[t]{2}{*}{$\begin{array}{l}\text { Parenting } \\
\text { Education }\end{array}$} & $\begin{array}{c}\text { Peran Pendidik } \\
\text { PAUD }\end{array}$ & 47,9 & -- & 47,9 \\
\hline & $\begin{array}{c}\text { Peran Petugas } \\
\text { PLKB }\end{array}$ & 21,5 & -- & 21,5 \\
\hline $\begin{array}{l}\text { Pola Asuh } \\
\text { Anak }\end{array}$ & $\begin{array}{l}\text { Peran Bidan } \\
\text { Desa }\end{array}$ & 5,7 & 6,6 & 12,3 \\
\hline \multirow{4}{*}{$\begin{array}{c}\text { Secara } \\
\text { Holistik }\end{array}$} & Peran Kader & 5,7 & $-0,5$ & 5,2 \\
\hline & $\begin{array}{c}\text { Peran Pendidik } \\
\text { PAUD }\end{array}$ & 12,3 & 25,8 & 38,1 \\
\hline & $\begin{array}{c}\text { Peran Petugas } \\
\text { PLKB }\end{array}$ & 20,0 & 11,6 & 31,6 \\
\hline & $\begin{array}{c}\text { Proses } \\
\text { Promosi } \\
\text { Kesehatan } \\
\text { Melalui } \\
\text { Parenting } \\
\text { Education }\end{array}$ & 53,8 & -- & 53,8 \\
\hline
\end{tabular}

Hasil analisis di atas membuktikan bahwa peran bidan desa, peran pendidik PAUD, dan peran petugas PLKB berkontribusi secara signifikan terhadap pola asuh orangtua secara holistik baik langsung maupun tidak langsung melalui proses promosi kesehatan melalui parenting education di PAUD Holistik Integratif Kabupaten Karanganyar. Namun, peran kader hanya berkontribusi secara signifikan terhadap pola asuh orangtua secara holistik secara langsung terhadap pola asuh orangtua di PAUD Holistik Integratif Kabupaten Karanganyar.

Model keterpaduan belum mendukung tercapainya tujuan PAUD Holistik Integratif, dalam arti belum sinergis, karena masing-masing kegiatan hanya fokus pada waktu pelaksanaan kegiatan, atau dengan kata lain hanya mempertimbangkan efisiensi waktu, yang belum memadukan materi penyuluhan. Salah satu kader menyatakan bahwa untuk pelaksanaannya agar lebih efektif sewaktu penimbangan, maka jika ada masalah dengan anaknya, terutama tentang pertumbuhannya, baru ibu-ibunya dikasih pengarahan oleh kader BKB saja. Oleh karena itu, dilihat dari angka pengaruh langsung terhadap pola asuh, peran petugas PLKB adalah lebih besar dibanding dengan peran bidan desa. Pengaruh langsung (direct effects) dari peran bidan desa terhadap pola asuh anak secara holistik di PAUD Holistik Integratif Kabupaten Karanganyar adalah sebesar 5,7\%, sedangkan pengaruh langsung (direct effects) dari peran petugas PLKB terhadap pola asuh anak secara holistik di PAUD Holistik Integratif Kabupaten Karanganyar adalah sebesar 20,0\%.

Selama ini bidan desa hanya memperhatikan pada kegiatan Posyandu saja, sedangkan program parenting education di PAUD kurang tersentuh oleh bidan desa. Bidan desa jarang atau bahkan ada yang belum pernah menjadi fasilitator dalam program parenting education. Walaupun wilayah penelitian merupakan PAUD Holistik Integratif, yang seharusnya bidan mempunyai peran di dalamnya, dari hasil wawancara dengan bidan desa di semua wilayah penelitian, bidan desa belum mengetahui tentang konsep parenting education. Kerjasama lintas sektor juga belum terlaksana secara maksimal. Hanya sewaktu-waktu, mereka mengadakan kegiatan Posyandu saja bersama-sama untuk mengevaluasi tentang pertumbuhan balita di wilayah tersebut. Sejalan dengan penelitian Etzioni (1993) dalam Syakrani (2004) yang mengajukan preskripsi, tumbuh kembang anak bukan hanya ditentukan oleh kekuatan yang ada dalam institusi keluarga. Stakeholders adalah pengambil keputusan yang diharapkan bisa berperan sebagai pengembang 
lingkungan tumbuh kembang anak. Namun, kemampuannya sebagai agent of socialization akhirakhir ini menurun.

Keterbatasan waktu, tenaga dan biaya membuat petugas PLKB kurang maksimal dalam melaksanakan perannya. Hal ini terlihat dari pengaruh tak langsungnya (indirect effects) melalui proses promosi kesehatan melalui parenting education yang lebih kecil, yaitu 11,6\%. Petugas PLKB jarang datang di setiap kegiatan BKB. Hal tersebut seperti dituturkan oleh salah satu kader BKB bahwa PLKB sangat jarang datang, setengah tahun sekali, dan susah dihubungi lewat telepon. Begitupula dengan peran bidan desa, pengaruh tak langsung (indirect effects) melalui proses promosi kesehatan melalui parenting education adalah sangat kecil, yaitu sebesar $6,6 \%$. Peran bidan selama ini hanya pada kegiatan Posyandu saja dan terfokus pada penimbangan.

Akibatnya, pembinaan terhadap kader dinilai kurang karena hanya dilaksanakan secara kolektif di tingkat desa bahkan ada yang di tingkat kecamatan. Petugas PLKB maupun bidan desa melaksanakan pembinaan jika ada momentum tertentu, seperti lomba kader BKB telatan, lomba Balita, dan lomba-lomba lainnya. Hal ini seperti yang diungkapkan salah satu kader bahwa rakor PKK diadakan apabila ada pembinaan khusus kader PKK, dan yang diundang adalah, antara lain, ketua, bendahara, sekretaris, pokja 1-4, kader BKB, kader Posyandu, dan 7 orang masing-masing desa. Mereka selalu mengklaim bahwa BKB dan Posyandu tidak berjalan sebagaimana yang diharapkan, dikarenakan faktorfaktor eksternal, misalnya kesadaran masyarakat yang masih rendah, rendahnya kualitas kader, dan sebagainya. Akan tetapi, mereka tidak pernah berupaya mencari solusi berangkat dari dalam dirinya, baru kemudian ke orang lain.

Pemahaman kader terhadap materi penyuluhan disimpulkan kurang optimal, sehingga peran kader hanya memberikan pengaruh langsung (direct effects) saja terhadap pola asuh anak secara holistik di PAUD Holistik Integratif Kabupaten Karanganyar yang hanya sebesar $5,7 \%$ dan tidak memberikan pengaruh tak langsungnya (indirect effects) melalui proses promosi kesehatan melalui parenting education. Selain itu, kader jarang bahkan ada yang belum pernah menerima pelatihan/pembekalan tentang program BKB maupun Posyandu apalagi parenting education yang merupakan program baru dibanding program BKB dan Posyandu. Kondisi kader seperti ini menyebabkan kemampuan kader menjadi terbatas. Pengetahuan kader BKB sendiri hanya sebatas dari buku panduan, seperti ungkapan beberapa kader yang disuruh belajar sendiri.

Selain itu, permasalahan kader baik kader BKB maupun kader kesehatan lain terutama di daerah pedesaan mempunyai permasalahan yang hampir sama, antara lain, kelangkaan kader, sehingga tidak jarang seorang kader memangku jabatan rangkap. Kecenderungan posisi kader ini juga dijalankan secara inklusif dengan istri-istri dari aparat desa, ibu RW, dan ibu RT. Oleh karena itu, figur ini sering terlihat pada sejumlah program kegiatan, seperti kegiatan PKK, Posyandu, Dasawisma, dan BKB. Terfokusnya para kader pada istri aparat desa (terutama Kepala Dusun), ibu RW ataupun ibu RT, dan rendahnya pendidikan yang mereka miliki, menjadikan kredibilitas fasilitator yang dijalankan oleh para kader yang terbatas itu tidak memberi hasil yang memadai.

Hasil pengamatan di lapangan menunjukkan bahwa kredibilitas kader ketika menyampaikan pesan program tidak muncul dalam arti yang sebenarnya. Kredibilitas tersebut ada namun dalam arti secara artificial, karena kepatuhan dan keinginan mendengar peserta terhadap materi kader dalam program itu adalah atas pertimbangan "pakewuh" karena kader adalah ibu RT atau RW setempat. Bahkan, sedikit demi sedikit peserta meninggalkan kegiatan tersebut tanpa ada rasa "pakewuh" sama sekali karena memang yang menjadi fasilitator adalah sesama warga.

Namun demikian, masalah kelangkaan kader yang disebabkan oleh minat yang rendah untuk menjadi kader dan kredibilitas kader yang rata-rata belum seperti yang diharapkan bukan berarti mereka tidak mempunyai komitmen. Keberhasilan programprogram yang dilaksanakan di desa selama ini juga 
ditentukan oleh kader-kader yang militan. Sekalipun pemerintah kurang berpartisipasi, kader-kader militan ini tetap mau dan rela menggerakkan anggota masyarakat untuk berpartisipasi dalam kegiatan. Bahkan, mereka rela untuk mengeluarkan dananya sendiri agar kegiatan ini berjalan. Orientasi penting mereka terhadap kegiatan ini adalah kebersamaan dan saling tukar informasi yang dapat dijalankan di masyarakat atau di desanya. Hal tersebut seperti penuturan salah seorang pendidik PAUD yang merangkap juga sebagai kader bahwa niatnya hanya ibadah, tidak ada imbalan lainnya.

Pengaruh langsung (direct effects) dari peran pendidik PAUD terhadap pola asuh anak secara holistik di PAUD Holistik Integratif Kabupaten Karanganyar adalah sebesar $12,3 \%$, sedangkan pengaruh tak langsungnya (indirect effects) melalui proses promosi kesehatan melalui parenting education adalah sebesar $25,8 \%$, yang tergolong besar dibanding dengan peran stakeholders yang lain. Hal ini juga dikarenakan sudah menjadi tanggungjawab pengelola/pendidik PAUD untuk menyelenggarakan program parenting education sesuai dengan Permendiknas RI. No. 31 tahun 2007 tentang Organisasi dan Tata Kerja Direktorat Jenderal Pendidikan Non formal dan Informal.

Pendidik PAUD telah melaksanakan perannya baik sebagai motivator, dinamisator, fasilitator, maupun pembina. Dengan demikian, harapan mengenai peran pendidik PAUD dapat terwujud, sebagaimana peran fasilitator yang disampaikan oleh Mardikanto (2010) bahwa peran fasilitator tidak hanya terbatas pada fungsi menyampaikan inovasi dan mempengaruhi proses pengambilan keputusan yang dilakukan oleh penerima manfaat, tetapi harus mampu mengorganisasikan, memotivasi, dan menggerakkan termasuk juga melakukan peran bantuan dan advokasi kebijakan yang diperlukan penerima manfaat.

Program parenting education yang ditujukan untuk pendidikan orangtua merupakan program strategis dalam upaya mendukung pertumbuhan dan perkembangan anak. Program tersebut merupakan program pemberdayaan (empowerment) orangtua yang memuat kegiatan promosi kesehatan. Kajian pada penelitian ini merupakan kajian strategi pemberdayaan (empowerment) orangtua dalam kegiatan promosi kesehatan yang ditujukan kepada faktor predisposisi dalam bentuk penyuluhan dengan pendekatan educational.

Pengaruh langsung (direct effects) dari proses promosi kesehatan melalui parenting education terhadap pola asuh anak secara holistik di PAUD Holistik Integratif Kabupaten Karanganyar adalah sebesar 53,8\%. Hasil analisis di atas membuktikan bahwa proses promosi kesehatan melalui parenting education berkontribusi secara signifikan terhadap pola asuh orangtua secara holistik di PAUD Holistik Integratif Kabupaten Karanganyar. Hal tersebut menerangkan bahwa pola asuh orangtua secara holistik akan sangat ditentukan oleh seberapa efektif proses promosi kesehatan melalui parenting education. Semakin besar dan baik proses promosi kesehatan melalui parenting education, maka semakin besar pola asuh orangtua secara holistik yang dijalankan. Hasil-hasil kajian menunjukkan bahwa lingkungan asuhan terutama interaksi ibuanak, pola asuh, dan stimulasi keluarga mempengaruhi pertumbuhan dan perkembangan anak, selain karakteristik keluarga, ibu dan anak, serta konsumsi makanan (Satoto, 1990; Madanijah, 2005).

Pemateri lebih sering disampaikan oleh pendidik PAUD yang berasal dari kader Posyandu ataupun dari kader BKB yang tidak memiliki latar belakang pendidikan yang memadai, jarang atau bahkan belum pernah dari bidan desa ataupun petugas PLKB secara langsung, sehingga pengetahuan yang didapat adalah kurang, karena para kader tidak pernah mempelajari baik metode maupun media dalam memberikan penyuluhan. Metode dan sarana prasarana memberikan pengaruh negatif karena ketersediaan dan kelayakan sarana dan prasarana (media) untuk menyampaikan materi juga tidak tersedia. Padahal, pesan-pesan yang disampaikan dengan menggunakan media pada umumnya tidak mudah hilang dari ingatan penerima (orangtua) (Ibrahim dkk, 2003). Berdasarkan hasil penelitian, materi pola asuh orangtua secara holistik dengan menggabungkan materi dari kegiatan BKB, Posyandu, PAUD berbasis keluarga serta 
ditambahkan materi Dasa Citra Anak Indonesia menjadi seperti berikut ini:

a. Kemampuan pemeliharaan kesehatan anak, yang meliputi: kemampuan orangtua untuk menyediakan P3K di rumah, dengan melakukan penanganan pertama kecelakaan pada anak, melakukan deteksi dini jika anak sakit, mengobatkan anak jika anak sakit, mengimunisasikan anak secara lengkap, dan mengajak anak untuk berolahraga.

b. Kemampuan mengasuh anak, yang meliputi: kemampuan orangtua untuk menerapkan stimulasi motorik pada anak sesuai tahap perkembangan anak, menerapkan stimulasi kognitif pada anak sesuai tahap perkembangan anak, dan menerapkan stimulasi bahasa dan interaksi sosial pada anak sesuai tahap perkembangan anak

c. Kemampuan pemenuhan gizi, yang meliputi: kemampuan orangtua untuk mengolah makanan yang bergizi, mengatur makanan yang bergizi dan pencegahan makanan yang tidak aman bagi kesehatan anak, membuat rencana menu, membuat kreasi menu, menggunakan sumberdaya yang ada disekitar rumah untuk memenuhi kebutuhan gizi, memantau pertumbuhan dan perkembangan anaknya, dan memotivasi anak untuk makan jika anak tidak mau makan.

d. Kemampuan perawatan anak, yang meliputi: kemampuan orangtua dalam melakukan perawatan kebersihan badan pada anak, merawat anak ketika anak sakit, dan menyediakan rumah/ pemukiman yang layak pada anak.

e. Kemampuan perlindungan anak, yang meliputi: kemampuan orangtua untuk menerapkan hak-hak anak dalam keluarga dan menerapkan lingkungan rumah yang aman dan nyaman untuk bermain anak di rumah.

f. Kemampuan mendidik anak, yang meliputi: kemampuan orangtua untuk menerapkan perilaku mendidik di rumah, membuat jadwal sederhana dalam kehidupan sehari-hari (bercerita, memasak bersama, dll), memberikan pendidikan religius pada anak, mengajarkan toleransi pada anak, mengajarkan kedisiplinan pada anak, mengajarkan tentang demokratis pada anak, menanamkan rasa ingin tahu pada anak, menanamkan rasa cinta tanah air, mengajarkan pada anak bagaimana menghargai prestasi, berkomunikasi secara baik dengan anak, mengajarkan nilai kejujuran pada anak, mendidik anak untuk kreatif, mengajarkan kemandirian pada anak, mengajarkan pada anak bagaimana menghargai prestasi, menanamkan rasa cinta damai pada anak, mengajak anak untuk gemar membaca, mengajarkan anak untuk peduli lingkungan, dan mengajarkan anak untuk peduli sosial/bersahabat kepada/dengan anak lain.

\section{KESIMPULAN}

Berdasarkan hasil analisis data dan pembahasan, kesimpulan yang dapat diambil adalah bahwa secara bersama-sama (simultan) peran bidan desa, peran kader kesehatan, peran pendidik PAUD, peran petugas PLKB, dan proses promosi kesehatan melalui parenting education berpengaruh signifikan baik langsung maupun tidak langsung terhadap pola asuh orangtua secara holistik. Secara parsial, peran bidan desa, peran pendidik PAUD, peran petugas PLKB serta proses promosi kesehatan melalui parenting education berpengaruh signifikan terhadap pola asuh orangtua secara holistik.

Dari temuan-temuan tersebut, peneliti menyarankan bahwa strategi parenting education yang tepat adalah penyediaan informasi yang memadai dan peningkatan kompetensi pemateri, yang meliputi penguasaan materi, kemampuan berkomunikasi, ketepatan metode, penggunaan berbagai teknik penyuluhan, dan penggunaan media yang tepat. Peningkatan kerjasama lintas sektor yang sangat penting untuk dilaksanakan adalah kerjasama antara Dinas Kesehatan, Dinas Pendidikan dan Olahraga serta Kantor BP3AKB. Petugas PLKB, bidan desa, serta pendidik PAUD dapat berfungsi sebagai penanggungjawab operasional. Lembaga-lembaga ini perlu menyusun sebuah kebijakan publik bersama tentang parenting education yang komprehensif, sehingga program pelembagaan promosi kesehatan melalui parenting education holistik integratif memiliki basis kebijakan publik yang kuat dan lembaga penanggunjawab dapat menjalankan tugas atau fungsinya dengan landasan yang lebih pasti. 


\section{UCAPAN TERIMA KASIH}

Ucapkan terima kasih dan penghargaan yang setinggi-tingginya kepada Prof. Bhisma Murti, dr. MPH., M.Sc., Ph.D, Dr. Sapja Anantanyu, SP, M.Si, MS serta Dr. Mahendra Wijaya, M.S. Beliau bertiga dengan kepakaran yang melekat telah meluangkan waktu dan memberikan kontribusi bimbingan bagi terwujudnya penelitian ini. Lembaga Penelitian dan Pengabdian Kepada Masyarakat, Dirjen Dikti yang telah membantu pembiayaan penelitian ini lewat hibah disertasi doktor. Penelitian ini merupakan bagian dari disertasi doktor peneliti. Terima kasih pula kepada lembaga: (1) PAUD Nakita Wetan Kali, Girilayu, Matesih; (2) PAUD Kasih Bunda Panjang, Sepanjang, Tawangmangu; (3) PAUD Mawar Putih Krangean, Ngeblak, Tawangmangu; (4) PAUD Amanah Dagen, Dagen, Jaten; (5) PAUD Seruni Sehat J1. Jeruk 03 Ngringo, Jaten sebagai tempat penelitian.

\section{DAFTAR PUSTAKA}

Brannen, J. 2002. Memadu Metode Penelitian Kualitatif Dan Kuantitatif. Yogyakarta: Pustaka Pelajar.

Bronfenbrenner, U. 1979. The Ecology Of Human Development. Harvard University Press, New York.

Butterfield KD., Reed R., and Lemak DJ. 2004. An Inductive Model of Collaboration from the Stakeholder's Perspective. Business and Society, Vol. 43 No. 2, p. 162-195 Washington State University: SAGE Publications.

Departemen Kesehatan Republik Indonesia. 2005. Kebijakan Nasional Promosi Kesehatan. Jakarta.

1997. Buku Panduan Manajemen Penyuluhan Kesehatan Masyarakat Tingkat Propinsi. Jakarta: Depkes RI.

Etzioni, A. 1993. Children Of The Universe: Who Care About Kids. Dalam Utne Reader Mei/Juni 1993.

Handayani Dkk. 2011. Peningkatan Kualitas Pos PAUD Melalui Pengembangan Program Holistik Integratif (Penelitian Tindakan Pada Pos PAUD Se-Kalurahan Penggaron Kidul). Jurnal Penelitian PAUDIA, Volume 1 No.1
Hsin. 2008. Parenting, Investments In Children, And The Social Reproduction Of Skills And Status. Dissertation Of University Of California. Los Angeles.

Ibrahim, J. T,. A. Sudiyono Dan Harpowo. 2003. Komunikasi Dan Penyuluhan Pertanian. Malang: Bayu Media Publishing.

Kementerian Pendidikan Nasional. 2011. Kerangka Besar Pembangunan PAUD Indonesia 20112025. Direktorat Pembinaan Pendidikan Anak Usia Dini Direktorat Jenderal Pendidikan Anak Usia Dini, Nonformal, Dan Informal.

Kitaoka Dkk. 2013. Efficacy Of A Group-Based Parenting Program On Stress And SelfEfficacy Among Japanese Mothers: A QuasiExperimental Study. Journal Of Nursing And Health Sciences (Nurs Health Sci) 2013 Jun 3. Date Of Electronic Publication: 2013 Jun 3.

Larne Dkk .2009. Predicting Participation In Group Parenting Education In An Australian Sample: The Role Of Attitudes, Norms, And Control Factors. Journal Of Primary Prevention $\underline{30.2}$ (Mar 2009): 173-89.

LIPI. 1998. Widyakarya Nasional Pangan Dan Gizi. VI

Madanijah, S. 2005. Model Pendidikan "GI-PSISEHAT" Bagi Ibu Dan Dampaknya Terhadap Perilaku Ibu Dan Lingkungan Pembelajaran Anak Usia Dini. Disertasi Institut Pertanian Bogor. Bogor.

Mardikanto. 2010. Komunikasi Pembangunan, Acuan Bagi Akademisi, Praktisi, Dan Peminat Komunikasi Pembangunan. Surakarta: UNS Press.

Midgley, James. 1986. Community Participation, Social Development And The State. London: Methuen.

Morgan, 2009. Parent And Teacher Perceptions Of Effective Parental Involvement. A Dissertation Presented To The Faculty And School Of Education Liberty University In Partial Fulfillment Of The Requirements For The Degree Doctor Of Education.

Mulyasa, E. 2012. Manajemen Pendidikan Karakter. Jakarta: Bumi Aksara.

Mursitho. 2014. Karakter Bangsa Yang Hilang. Ka. Pusdiklatnas Kwartir Nasional. Kompasiana. 
Tri Sunarsih

Peran Bidan dalam Parenting education....

Nomi, 2014. Kartu Indonesia Pintar (KIP) VS Bantuan Operasional Sekolah (BOS).

Sekretaris Jenderal Barisan Nusantara Dan Anggota Badan Akreditasi Pendidikan Nonformal (BAN PNF). Jakarta

Permendiknas RI. No. 31 tahun 2007 tentang Organisasi dan Tata Kerja Direktorat Jenderal Pendidikan Non formal dan Informal.

Sandjojo, N. 2011. Metode Analisis Jalur Dan Aplikasinya. Jakarta: Pustaka Sinar Harapan.

Satoto. 1990. Pertumbuhan Dan Perkembangan Anak. Pengamatan 0-18 Bulan Di Kecamatan Mlonggo, Kabupaten Jepara, Jawa Tengah. Disertasi Program Pascasarjana Universitas Diponegoro. Semarang.

Shochib, M. 2010. Pola Asuh Orangtua. Jakarta: PT Rineka Cipta.

Siregar YR. 2014. Perilaku Seksual Bebas Remaja Di Kecamatan Medan. Jurnal Fakultas Keperawatan Universitas Sumatera Utara, 2014

Syakrani. 2004. Pengembangan Sumberdaya Manusia Berbasis Keluarga : Telaah Pengaruh Detrimental Pola "Keayahbundaan" Orangtua Yang Tidak Sehat Terhadap Defisit Karakter Pada Anak-Anak. Disertasi Program Pasca Sarjana Institut Pertanian Bogor. Bogor 